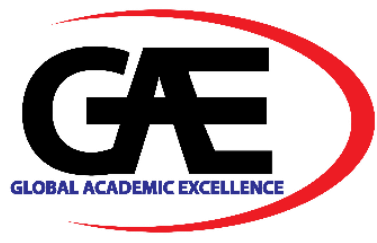

\title{
METACOGNITIVE AWARENESS OF LISTENING STRATEGIES AND PERCEPTION OF LISTENING SKILL DURING REMOTE LEARNING
}

\author{
Nur Anneliza Abd Latip ${ }^{1}$, Iziana Hani Ismail2*, Wardatul Akmam Din ${ }^{3}$, Suyansah Swanto ${ }^{4}$ \\ 1 Preparatory Centre for Science and Technology, Universiti Malaysia Sabah, Malaysia \\ Email: nuranne@ums.edu.my \\ 2 Preparatory Centre for Science and Technology, Universiti Malaysia Sabah, Malaysia \\ Email: iziana.hani@ums.edu.my \\ 3 Faculty of Psychology and Education, Universiti Malaysia Sabah, Malaysia \\ Email: wardadin@ums.edu.my \\ $4 \quad$ Faculty of Psychology and Education, Universiti Malaysia Sabah, Malaysia \\ Email: suyansah@ums.edu.my \\ Corresponding Author
}

\section{Article Info:}

Article history:

Received date: 11.09 .2021

Revised date: 10.10 .2021

Accepted date: 15.11 .2021

Published date: 30.11 .2021

To cite this document:

Abd Latip, N, A., Ismail, I, H., Din, W, A., \& Swanto, S. (2021). Metacognitive Awareness of Listening Strategies and Perception of Listening Skill During Remote Learning. Journal of Information System and Technology Management, 6 (23), 81-94.

DOI: $10.35631 / J I S T M .623007$

\begin{abstract}
:
The online classes associated with the Covid-19 pandemic have resulted in the magnitude of remote learning of ESL (English as a second language). Sustaining the quality of teaching and learning of listening skills has become more challenging for everyone. Listening is one of the fundamental skills to acquire knowledge in an academic setting. Every instructor and learner need to perceive that listening is not an innate skill, understand the processes involved in listening comprehension, and integrate strategies while listening. The present study explores Metacognitive Awareness of Listening Strategies (MALS) and students' perceptions about learning listening skills during remote learning. The current study was conducted through a multimethod research design where both quantitative and qualitative data were involved. Two instruments were utilised, which are the Metacognitive Awareness of Listening Questionnaire (MALQ) and the online discussion board. The participants were chosen based on simple random sampling consisting of 51 pre-university students enrolled in the Science Foundation programme in the 2020/2021 session. The first part of the results depicted students had an average level of MALS with directed attention strategies as the factor with the highest average. The second part of the results reported that students who scored a higher average score of MALS tend to use problem-solving strategies. Lastly, the
\end{abstract}


Volume 6 Issue 23 (November 2021) PP. 81-94 DOI: 10.35631/JISTM.623007

Special Issue: Foundation Program Education Post-Covid-19: Issues and Opportunities

This work is licensed under $\underline{\text { CC BY } 4.0}$

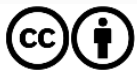

board postings were analysed thematically and categorised to three different themes which are challenges, strategies, and activities of learning skills. It is hoped that this study will shed light on empirical strategies and evidence of listening practices during online classes. Both teachers and learners may have clearer insights on how to manage listening comprehension effort and use learning inherent to tackle remote learning.

Keywords:

Listening Skill, Metacognitive Awareness Of Listening Strategies, Remote Learning, Pre-University Students

\section{Introduction}

The overwhelming impact of the pandemic has put language learning to be more challenging and global trends demand the teachers to be adaptable and recalibrating the pedagogical. Although these challenges have continued to prevail, empirical studies have been done to address the issue and suggest ways to resolve, thus putting resiliency towards the teachers and students. The Covid-19 pandemic affected the universities throughout the world, making students learned remotely using e-learning tools to curb the spread of the disease (Huang, 2021). Students do not get to interact face to face with their teachers and the traditional classroom learning immediately shifts to computer-based learning (Lall \& Singh, 2020).

The sudden implementation of Movement Control Order (MCO) shows students in Malaysia to use platform such as Google Meet and Webex for synchronous activities. Teachers were struggling to tackle the technological challenges and may affect the effectiveness of the students' learning process, since the operation and purpose of online education during the pandemic is not only for blended learning but to cater for the whole course (Wen \& Kim Hua, 2020). The weighting now lies in the performance of online classes. In ESL, challenges come from many angles. It may be impossible that all four skills of English language are equally updated (Nurkhamidah, 2021).

Conducting listening skill in a full online format is a new experience for the instructors and students in university. In a traditional classroom the recording is managed by the teacher, but in online learning, the audio must be delivered to a certain platform, then students compelled to be independent in managing the audio (Nurkhamidah, 2021). In return, not all students might get the same output due to poor internet connections. Students also stated that the quality of listening, and speaking was not maintained during online class and did not fully helping students' English ability (Hartshorn \& McMurry, 2020). The limitation of learning activities in listening skill making that skill became less improved (Famularsih, 2020).

Even though instructors are unable to observe them directly in class during remote learning, it is vital to investigate the process of listening involved and how strategies can be used to manage comprehension efforts. Learners should grasp the idea that they can use strategies to improve their listening ability and have the autonomy to incorporate strategies in their listening process instead of only hearing audio (Vandergrift, 2004). Possessing metacognitive awareness and the perception that using listening strategies can help listeners capitalise on the language input received, manage the approaches before listening, focus on the spoken message, and therefore enhance their performance on listening task (Vandergrift, 2004). This awareness is related to 
Special Issue: Foundation Program Education Post-Covid-19: Issues and Opportunities the way listeners think about listening process; plan, monitor, and evaluate the listening task; and tackle the problems they face during listening (Vandergrift, Goh, Mareschal, \& Tafaghodtari, 2006).

Besides practices given by the instructors, it is also suggested that students do more intensive exercises to strengthen their listening skills such as listening to song or movie to maintain the enthusiasm during the pandemic (Aldina \& Haura, 2020). Technology can be optimised meaningfully by instructors and students to facilitate language learning materials (Famularsih, 2020). Authentic audio materials can be one of the choices techniques to learn listening skill such as quiz show, video, movies or radio dramas (Febiyanti, Nitiasih, Budiarta \& Adnyayanti, 2021). Furthermore, students also preferred to learn simple monologue or dialogue using video and texts with picture so that they can learn useful expression (Destianingsih, \& Satria, 2020).

Therefore, this study attempts to explore MALS and students' perception about listening during remote learning when they were affected with Covid-19 pandemic. The present study aims at finding answers to the following questions:

i. What is the level of metacognitive awareness of listening strategies among preuniversity students during remote learning?

ii. What is the relationship between the factors and overall score of metacognitive awareness of listening strategies during remote learning?

iii. What are the students' perceptions about learning listening skill remotely?

\section{Literature Review}

Listening is a crucial skill and should be considered as the primary channel of learning a language as it allows language learners to receive the input and at the same time develop other language skills (Vandergrift \& Goh, 2012; Nation \& Newton, 2009). Subsequently, it is also an important skill for employability and a lifelong skill developed in the university setting. This is because listening skill is fundamental for tertiary learning and effective listening comprehension skills can contribute to academic achievement (Vandergrift, 2004). Listening comprehension problems were accentuated by many experts to improve learning. However, listening skill is the least prominent and seldom tackled compared to other language skills. According to Rost (2002) and, Vandergrift and Tafaghodtari (2010), listening skill in many language learning settings worldwide is perceived as an overlooked skill due to lack of instructional development by the teacher. Subsequently, there is a limited empirical approach to listening and this might be due to the nature of listening itself as Takei (2002) refers it as a cognitive process and therefore difficult to observe. Despite the call, listening in ESL is often underrated.

The nature of listening skill is less observable compared to other skills (Graham, 2006). Students often have no control over input and cannot rewind or pause if the audio is too fast. Such transitory nature of such oral input is causing them listening anxiety (Graham, 2011). Students also showed signs of demotivation in relation to listening, and very few of them choose listening as a strength (Graham, 2016). This is far too different compared to writing skill. In the past few decades, listening is not recognised as a passive activity anymore 
Volume 6 Issue 23 (November 2021) PP. 81-94 DOI: 10.35631/JISTM.623007

Special Issue: Foundation Program Education Post-Covid-19: Issues and Opportunities (Rahimirad \& Zare-ee, 2015). Many language experts and researcher emphasised the crucial awareness and intervention to accentuate learning comprehension.

\section{Listening Skill Problem}

Listening skill is a challenging task for ESL learners. According to Vandergrift (2007), the characteristic of listening that makes it difficult is that listening is an invisible mental process making it difficult to describe. The process can be overwhelming as learners need to engage in many things such as distinguishing accent, understanding vocabulary, getting correct grammar, directing their attention and unfamiliar context (Vandergrift, 2007). The most common problems faced by students in listening in the order of frequency are quickly forgetting what is heard, unrecognised words, understanding the message but not the intended message, neglecting next part while thinking about meaning, failing to form a mental representation from words heard and the problem of concentrating and missing the beginning of text (Goh, 2000).

Listening skill is not only essential to university students but also graduates. Some analysis depict that our students face great difficulties in understanding lectures in English and do not retain the correct listening skills (Abdul Aziz and Ismail, 2005; Selamat \& Sidhu, 2011). Preuniversity students and with poor listening skill performance may affect their degree study since at Malaysian tertiary level, almost all courses are taught in the English language where students are expected to understand the subject matter, respond appropriately and completing assessment (Ahmad \& Abidin, 2020), thus making it crucial for students to tackle this at preuniversity level.

\section{Metacognitive Awareness of Listening Strategies}

Metacognitive awareness refers broadly to these manifestations revealing a person's consciousness of personal thoughts and conscious actions (Vandergrift \& Goh, 2012). Five distinct factors: directed attention, mental translation, planning and evaluation, problem solving, and person knowledge are crucial to the learning process as metacognitive knowledge can influence the way an individual plans, manages and directs one's own learning (Vandergrift, 2006; Vandergrift \& Goh, 2012). Metacognitive awareness able to improve the level of students' listening performance and by training the teachers from the perspective of metacognition contributes to desirable educational goals (Rahimi \& Katal, 2011). Highly skilled listeners reveal using about twice as many metacognitive strategies compared to the less skilled, primarily in monitoring their comprehension (Vandergrift \& Goh, 2012). The explanation of the factors by Vandergrift, Goh, Mareschal and Tafaghodtari (2006) are shown in Table 1.

Table 1: Five factors of Metacognitive Awareness of Listening Strategies

Factor Definition

Problem Solving It represents a group of strategies used by listeners to inference (guess at what they do not understand) and to monitor these inferences. This include strategies such as using known words to deduce the meaning of unknown words, using the general idea of a text to deduce unknown words, using one's experience and general knowledge in interpreting the text, adjusting one's interpretation upon realising that it is not correct, monitoring the accuracy of one's inferences for congruency with the 
Special Issue: Foundation Program Education Post-Covid-19: Issues and Opportunities developing interpretation, and comparing the developing interpretation with one's knowledge of the topic.

Planning and It represents the strategies listeners use to prepare themselves for Evaluation listening, and to evaluate the results of their listening efforts. The items in this factor include strategies such as having a plan for listening, thinking about similar texts as a guide for listening, having a goal in mind while listening, periodically checking one's satisfaction with the ongoing interpretation while listening, and evaluating the strategic effectiveness of one's listening efforts.

\begin{tabular}{cl}
\hline $\begin{array}{c}\text { Mental } \\
\text { Translation }\end{array}$ & $\begin{array}{l}\text { It represents strategies that listeners must learn to avoid if they are to } \\
\text { becomes killed listeners. The items under this factor all tap the online } \\
\text { mental translation strategy. }\end{array}$ \\
\hline $\begin{array}{c}\text { Person } \\
\text { Knowledge }\end{array}$ & $\begin{array}{l}\text { It represents listeners' perceptions concerning the difficulty presented by } \\
\text { L2 listening and their self-efficacy in L2 listening. This includes items } \\
\text { assessing the perceived difficulty of listening compared with the three } \\
\text { other language skills, learners' linguistic confidence in L2 listening, and } \\
\text { the level of anxiety experienced in L2 listening }\end{array}$ \\
\hline Directed & $\begin{array}{l}\text { It represents strategies that listeners use to concentrate and to stay on task. } \\
\text { Attention } \\
\text { The items under this factor include strategies such as getting back on track } \\
\text { when losing concentration, focusing harder when having difficulty } \\
\text { understanding, recovering concentration when one's mind wanders, and } \\
\text { not giving up when one experiences difficulties understanding. }\end{array}$ \\
\hline
\end{tabular}

Source: Vandergrift et. al (2006)

\section{Methodology}

In consideration of the research purposes and questions previously presented, the current study was conducted through multimethod research design. Taskakkori \& Teddlie $(2010 \mathrm{a}, \mathrm{b})$, described multi-method studies as studies involving multiple types of qualitative research, multiple types of quantitative research or mixing of both types of data (Morse 2003, 2010). The methods were conducted concurrently but are not integrated until inferences are being made (Johnson, Onwuegbuzie \& Turner, 2007). Both qualitative and quantitative data were independent, and then used together to form essential components of one research findings. Furthermore, each method maintains its own perspective.

\section{Participants and Setting}

The participants were chosen based simple random sampling consists of 51 pre-university students enrolled in Science Foundation programme in 2020/2021 session. Two compulsory English courses were taken by the students. Academic English for Writing and Speaking was completed in the first semester and Academic English for Reading and Listening was taken during the second semester. The classes in semester two, where listening skill was attained online.

\section{Instruments}

Students' MALQ scores and discussion-board postings were the data sources for this study. In the first part, MALQ is used to assess language learners' awareness and perceived use of listening strategies (Vandergrift et al., 2006). The questionnaire contains 21 items, and each Copyright $\odot$ GLOBAL ACADEMIC EXCELLENCE (M) SDN BHD - All rights reserved 
Volume 6 Issue 23 (November 2021) PP. 81-94 DOI: 10.35631/JISTM.623007

Special Issue: Foundation Program Education Post-Covid-19: Issues and Opportunities item is rated on a 6-point Likert scale. The range from 1 (strongly disagree) to 6 (strongly agree) without a neutral point. The scale has five factors including problem solving (6 items), planning evaluation (5 items), mental translation ( 3 items), person knowledge ( 3 items), and directed attention (4 items). The reliability for each of the subscales are 0.780 (problem solving), 0.753 (planning and evaluation), 0.796 (mental translation), 0.735 (person knowledge), and 0.701 (directed attention). All the subscales showed Cronbach's Alpha values that is greater than 0.7, so the scale has relatively good internal reliability. Question 15 and 16 were deleted to improve the reliability of the questionnaire.

In the second part, students were asked to participate in an asynchronous online discussion using online board in Dotstorming. At the end of the second semester, students were asked to write discussion to reflect and evaluate their learning experience when learning the skills remotely. Students were asked about to tell their experience of learning listening skill online. Two questions were asked which involved their listening activities and experience. Students may write their answers in a form of bullet points or paragraph. Afterwards, authors download and analyse all the answers.

\section{Data Coding and Analysis}

Data analysis was conducted using the Statistical Package for Social Sciences 21 (SPSS) to answer the first and second research question. Descriptive test including means and standard deviation was conducted to find out the level of MALS. Then, reliability test was conducted to measure the inter-consistency of instrument items. Subsequently, parametric test, in which specific assumptions were made about the population parameter was used in this study. For measuring the degree of association between each subscale and average of MALS, Pearson's coefficient of correlation was used as a test. All MALQ items, the 6-point of scale chosen by the participants were coded as their scores for the items, except items 3 and 8 were reversecoded (Goh \& Hu, 2013; Vandergrift et al., 2006). The items were reverse coded for average since mental translation is a strategy than skilled listeners should avoid (Goh \& $\mathrm{Hu}, 2013$; Vandergrift et al., 2006). Mental translation subscale was reversed before the averaging was carried out (Vandergrift et al., 2006). The overall MALQ scale was derived by averaging each participant's scores for all the five subscales (Baleghizadeh \& Rahimi, 2011; Vandergrift et al., 2006; Zeng 2012).

Thematic analysis was used to answer the third research question. It is a method for identifying patterns of meaning across a dataset in relation to a research question. (Braun \& Clarke, 2013). Each of discussion board post was coded by the authors using Quirkos. The authors coded each post first individually and then jointly, with all discrepancies resolved by mutual agreement (Song \& McNary 2011). Three of the authors were instructors involved, which helped enhance the validity of coding (Song \& McNary 2011). Three new codes which are "listening activities", "difficulties", and "strategies" were added. Codes, defined as words or short phrases that captures the important input of why a particular data may be beneficial; were identified and given a label for a feature of the data that is possibly pertinent (Braun \& Clarke, 2013, p. 207). 
Volume 6 Issue 23 (November 2021) PP. 81-94 DOI: 10.35631/JISTM.623007

\section{Findings}

Special Issue: Foundation Program Education Post-Covid-19: Issues and Opportunities

This section is to report the quantitative and qualitative data analysis of this study. The descriptive statistic explanations of the participants and instruments involved are discussed. Results of the statistical data analysis and the qualitative findings of online discussion boards are thoroughly explained. Findings were supplemented with tables.

\section{Metacognitive Awareness of Listening Strategies}

Table 2 shows the descriptive analysis of the subscales and average of MALS. The mean for the overall MALQ is 4.816, implying an average level of metacognitive awareness as MALQ was measured by a 6-point Likert scale. Out of all 5 subscales, directed attention has the highest mean score which is 4.869 . This indicates students slightly agree to the directed attention strategies. This is followed by problem solving, planning and evaluation, and mental translation with 4.817, 4.462 and 4.085, respectively. Meanwhile, person knowledge has the lowest mean of 3.675. This depicts those students slightly disagree to listening skill as easy compared to skills. Subsequently, person knowledge has the highest variability where the standard deviation is 1.143, followed by mental translation, planning and evaluation, directed attention and problem solving with $1.101,0.820,0.811$ and 0.684 respectively.

Table 2: Descriptive Analysis of Metacognitive Awareness of Listening Strategies

\begin{tabular}{lllllll}
\hline & $\begin{array}{l}\text { Problem } \\
\text { Solving }\end{array}$ & $\begin{array}{l}\text { Planning } \\
\text { and } \\
\text { Evaluation }\end{array}$ & $\begin{array}{l}\text { Mental } \\
\text { Translation }\end{array}$ & $\begin{array}{l}\text { Person } \\
\text { Knowledge }\end{array}$ & $\begin{array}{l}\text { Directed } \\
\text { Attention }\end{array}$ & MALQ \\
\hline $\mathrm{N}$ & 51 & 51 & 51 & 51 & 51 & 51 \\
Mean & 4.817 & 4.462 & 4.085 & 3.675 & 4.869 & 4.816 \\
Median & 4.833 & 4.600 & 4.333 & 3.667 & 4.750 & 4.047 \\
Std. & 0.684 & 0.820 & 1.101 & 1.143 & 0.811 & 0.684 \\
Deviation & & & & & & \\
\hline
\end{tabular}

Table 3 shows the correlation analysis between the factors of metacognitive awareness of listening strategies and overall score. There was a very high positive correlation between the problem solving and the average score of MALQ, $\mathrm{r}=1.000, \mathrm{n}=51, \mathrm{p}=0.000$. This is the highest correlation compared to other subscales. It shows that students who has high overall score of MALS tend to use problem solving strategies compared to other subscales. The second highest positive correlation was directed attention, $r=0.643, \mathrm{n}=51, \mathrm{p}=0.000$, followed by planning and evaluation with $\mathrm{r}=0.634, \mathrm{n}=51, \mathrm{p}=0.000$. 
Volume 6 Issue 23 (November 2021) PP. 81-94 DOI: 10.35631/JISTM.623007

Special Issue: Foundation Program Education Post-Covid-19: Issues and Opportunities

Table 3: Correlation Analysis of Metacognitive Awareness of Listening Strategies

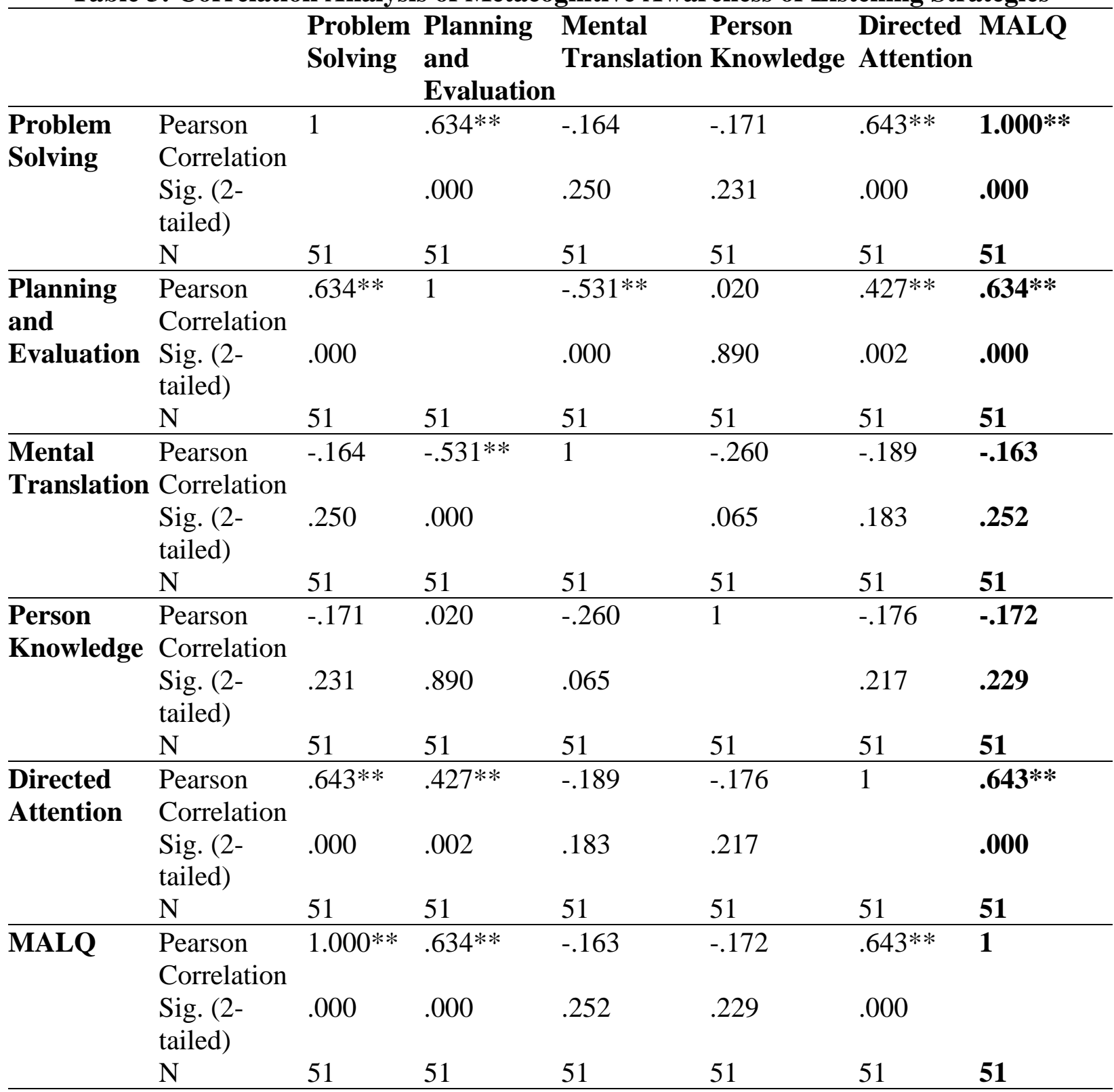

**. Correlation is significant at the 0.01 level (2-tailed).

\section{Students' Perception on Listening Difficulties}

Students shared perceived difficulties while developing their listening skill remotely using the Dotstorming online board. Table 4 depicts students' perception on their difficulties while attempting listening skill during remote learning. Apparently, multitasking is crucial when doing the listening practice. You must listen and at the same time selecting necessary information and preparing for the next section. Students are also challenged with accents that they are unfamiliar with. Some parts of listening can be confusing when it involves understanding vocabulary and getting the correct grammar. Another biggest challenge highlighted by the students was maintaining your focus. Staying attentive by relating to their previous knowledge and picturing what the speaker is trying to say can be challenging. 
Volume 6 Issue 23 (November 2021) PP. 81-94 DOI: 10.35631/JISTM.623007

Special Issue: Foundation Program Education Post-Covid-19: Issues and Opportunities Table 4: Students' Perception on Listening Skill Difficulties During Remote Learning

$\begin{array}{cl}\text { Student } & \text { Feedback } \\ 3 & \text { Listening requires us to be very alert and focus on every part because } \\ \text { it can be confusing if we skipped some parts. It is quite challenging } \\ \text { especially when listening to different accent which can be very } \\ \text { confusing for those who are not familiar with it. } \\ \text { I had a hard time multitasking and need to identify confusing } \\ \text { statements in the listening tracks. } \\ \text { Listening skill is not an easy to do because its need a lot of attention } \\ \text { while multitasking. } \\ \text { I realised that I am not good at multitasking because my thoughts like } \\ \text { to drift. I can't picture what the speaker is saying. } \\ \text { Having short attention span is really hard when it comes to listening. } \\ \text { I have learned not to underestimate in developing greater listening } \\ \text { skills as you have to have a good ability in finding the synonyms of } \\ \text { some phrases and a vast English lexicon. } \\ \text { Honestly, listening skills is quiet challenging for me, so I hear a lot of } \\ \text { accents that I'm not familiar with. } \\ \text { Sometimes it's hard for me to understand what people saying are } \\ \text { because of different slang/accent, lack of vocabulary and hearing } \\ \text { problem. }\end{array}$

\section{Students' Perception on Listening Strategies}

Table 5 describes students' feedbacks on their strategies when answering listening practices independently. Some of the practicing strategies that they mentioned, without realising, are also related to subscales in MALS. According to their feedbacks on the online board, when asked about their strategies before and while answering MUET listening, most of the responses encompass of strategies such as checking the question paper and reading the question carefully. Other than that, students highlighted keywords, and multitasking. A few of them mentioned about staying focus throughout the practice. Short attention span is a challenge especially when there were so many distractions at home. Being attentive helped them to interpret the information faster, link own ideas to question and avoid misunderstanding.

Table 5: Students' Perception on Listening Skill Strategies During Remote Learning

\begin{tabular}{cl}
\hline Student & \multicolumn{1}{c}{ Feedback } \\
\hline 4 & $\begin{array}{l}\text { I link my ideas to the questions well. } \\
\text { I focus more and interpret the information given faster. } \\
\text { I scan all the questions and highlight keywords as fast as possible. } \\
\text { Then, hear the conversation with full attention. } \\
\text { Pay attention, that's all. without the ability to listen effectively, } \\
\text { message is easily misunderstood. therefore, we must give the speaker } \\
\text { undivided attention to catch up at least the keywords. }\end{array}$ \\
$\begin{array}{l}\text { I know that my attention towards the conversations is important so, I } \\
\text { tried to be more attentive to the details. } \\
\text { I trained to do a multitasking work. It makes me more concentrate to } \\
\text { listen while answering the question. }\end{array}$ \\
\hline
\end{tabular}


26 Having short attention span is hard when it comes to listening. However, knowing how to pick the important parts in a conversation helps in countering that part of me. recording start and find the perfect seating (in the middle, near the speaker) to get the best sound quality. information. phrases and a vast English lexicon. similar answers/contexts, and this is when I applied what I have learned from the reading exercises.

4 We need to be more focus and find the accurate answer by looking at the questions properly.

\section{Students' Perception on Listening Activities}

Apart from the listening practices given by the instructors or from their MUET textbook, students also carried out few activities to improve their listening skill. Table6 shows students' feedbacks on activities that they have done while doing listening skill remotely. Students relied on Youtube in listening to movie review, documentary, and speeches. By listening to speeches, Subsequently, listening to radio announcer using British English help the student to get familiar with the accent. All these activities were initiated by students to make up for the missing face to face listening activities. In class, it is easier to conduct activity with the help of university facilities and appropriate tools. However, finding activities that one size fits all for listening practice remotely might be an arduous task as some students were struggling with the internet connection.

Table 6: Students' Perception on Listening Activities During Remote Learning

\begin{tabular}{|c|c|}
\hline Student & Feedback \\
\hline 1 & $\begin{array}{l}\text { I listen to any English conversation either from the movie or from } \\
\text { conversation with other people. }\end{array}$ \\
\hline 2 & I listen to English video and does not read the subtitles. \\
\hline 5 & I listen to the short video and interpret the information of the video. \\
\hline 22 & $\begin{array}{l}\text { Listening famous speech, which we did during class, gain me a lot of } \\
\text { incite such as formal lexicon and way of talking to gather attraction. }\end{array}$ \\
\hline 23 & I have been watching my favourite show with no subtitles \\
\hline 25 & I listen to audio taken from radio script by British English speakers. \\
\hline 32 & $\begin{array}{l}\text { By reading the MUET textbook on tips on answering the listening } \\
\text { skills questions and having multiple listening skills practices }\end{array}$ \\
\hline 33 & I figure out the main point of someone's speech. \\
\hline 42 & I will try listening to practices on youtube. \\
\hline 46 & $\begin{array}{l}\text { I have improved my listening skill because of interesting tasks like } \\
\text { movie review, documentary and others. }\end{array}$ \\
\hline 49 & I watch English movies without having to read the English subtitles. \\
\hline
\end{tabular}


my listening.

\section{Discussion}

Findings show that students had an average level of metacognitive awareness. Furthermore, the factor with the highest level of metacognitive awareness was directed attention, followed by problem solving, planning and evaluation, mental translation, and person knowledge. This echoes with other studies where students have average level of metacognitive awareness of listening strategies (Rahimi \& Abedi, 2014). In the context of EFL, a study by Tafarojiyeganeh (2013) showed metacognitive listening strategies among bilinguals were higher than monolinguals Iranian university students. A study by Rahimi and Katal (2011) found that girls' awareness in directed attention was significantly higher than boy.

This study also shows that students who had high average of MALS, tend to use problem solving strategies such as using known words or general ideas to deduce the meaning of unknown words, using one's experience and general knowledge in interpreting the text, adjusting one's interpretation upon realising that it is not correct, monitoring the accuracy of one's inferences for congruency with the developing interpretation, and comparing the developing interpretation with one's knowledge of the topic (Vandergrift et. al, 2006). Second mostly used strategies among those who has MALS were directed attention such as getting back on track when losing concentration, focusing harder when having difficulty understanding, recovering their concentration, and not giving up when one experiences difficulties understanding (Vandergrift et. al, 2006). The third highest correlation to the average of MALS is planning and evaluation which includes strategies such as having a plan for listening, thinking about similar texts as a guide for listening, having a goal in mind while listening, periodically checking one's satisfaction with the ongoing interpretation while listening, and evaluating the strategic effectiveness of one's listening efforts (Vandergrift et. al, 2006). Other studies found that bilingual students showed higher awareness in planning and evaluation and mental translation components (Tafarojiyeganeh, 2013). Further, English students were found to be more aware of their problem solving and planning and evaluation strategies and non-English majors were found to be more concern of their mental translation strategies. Some study shows different prominent awareness of metacognitive strategies such as problem solving, planning and evaluation, mental translation strategies (Rahimi \& Katal, 2011); directed attention, problem solving and person knowledge (Lee, 2018); and directed attention and problem solving (Goh \& $\mathrm{Hu}, 2013)$.

Students' difficulties when learning listening remotely was multitasking and maintaining focus. Different accents from different speaker also emphasise their anxiety as it is unfamiliar and confusing. So, the students' strategies were mostly reverberating with the strategies and activities that they shared. When the students were asked about strategies, students mostly settled with simple yet systematic approaches. It encompasses of strategies such as checking the question paper and reading the question carefully. Other than that, students highlighted keywords, and multitasking, and being attentive. Some the strategies that they mentioned are related to MALS without them realising it (Selamat \& Sidhu, 2013). Such strategies are directed attention where students used to concentrate and to stay on task. 


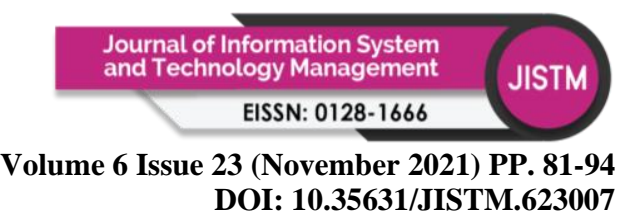

Special Issue: Foundation Program Education Post-Covid-19: Issues and Opportunities Students also shared their listening activities during the pandemic besides the exam practices in the textbook given by the teachers. Some of the activities were listening to movie review, documentary, and speeches in YouTube. They also get familiarised with the accent by listening to radio news. This is echoes with the study by Nurkhamidah (2021) where teachers need to present the materials with different types of accents to help in recognising the variety of English accents. Schmidt (2016) suggested a journal web-based activity where Ted Talk is being utilised initially without subtitle, then after few attempts of understanding, subtitle was allowed. Meanwhile, students in Indonesia had high positive perceptions towards authentic materials for listening like films, short video, and songs (Halim, Mukminatien \& Anugerahwati, 2018). Djabborova (2020) suggested two activities which are mock interview and authentic learning materials such as radio programs and voice mail messages. However, teachers' intervention must also be present to choose the appropriate learning material as common problem such as unfamiliar slang and idioms, high rate of speech, long text, and unfamiliar with the topic might occur (Nurkhamidah, 2021). The material used in listening class should be simpler than that one in offline class (Nurkhamidah, 2021).

\section{Implications and Conclusion}

The findings of this study can be impactful towards students to be able to self-direct and selfreflect their efforts to improve their listening process. Both learners and teachers should be aware that there is a process in listening comprehension just like other language skills (Vandergrift \& Goh, 2012). They should have a clear insight of the development in listening practice and how metacognitive awareness can be used to manage efforts in listening activities (Vandergrift \& Goh, 2012). Furthermore, the finding concerning students' perceptions and experience are very significant to tackle listening skill in a more challenging environment.

Listening comprehension should be viewed in a more principled manner during the remote learning process. Studying in their degree courses will require students to listen to variety of context in a more challenging environment. So, listening skill must be explored as it is one of the fundamental parts in comprehending knowledge. It is crucial for students' overall academic success. Hence, the finding concerning metacognitive awareness among pre-university students is significant to prepare them for their degree study (Selamat \& Sidhu, 2011).

\section{References}

Ahmad, I., \& Abidin, M. J. Z. (2020). Developing an Alternative Listening Comprehension Test to Benchmark Malaysian Undergraduates' Listening Performances. International Journal of Instruction, 13(2), 677-690.

Aziz, R. A. \& Ismail, M. R. (2005). An Analysis of Problems In Comprehending Academic Lectures. English in education: Issues and challenges in the Malaysian classroom (pp. 71-80). Shah Alam, Malaysia: Pusat Penerbitan Universiti, UiTM.

Aldina, M., Dayu, A. T., \& Haura, R. (2020). Students'challenges in Listening in Virtual Classroo; Case Study In English Education Study Program In Covid-19. Proceeding: Islamic University of Kalimantan, 1(1).

Braun, V., \& Clarke, V. (2013). Successful Qualitative Research: A Practical Guide for Beginners. London: Sage.

Destianingsih, A., \& Satria, A. (2020). Investigating students' needs for effective English online learning during Covid-19 for Polbeng students. ELT-Lectura, 7(2), 147-153. 


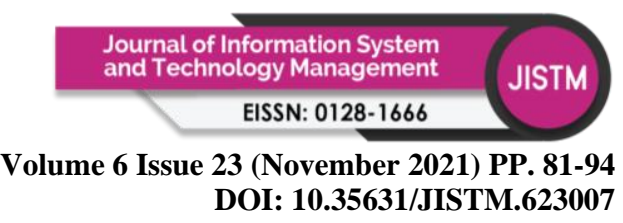

Special Issue: Foundation Program Education Post-Covid-19: Issues and Opportunities

Djabborova, F. O. (2020). Ways of developing listening skills of English learners in ESL and EFL classroom. European Journal of Research and Reflection in Educational Sciences, $8(10), 212-216$.

Famularsih, S. (2020). Students' experiences in using online learning applications due to COVID-19 in English classroom. Studies in Learning and Teaching, 1(2), 112-121.

Febiyanti, N. W., Nitiasih, P. K., Budiarta, L. G. R., \& Adnyayanti, N. L. P. E. (2021). The Effect of Project Based Learning Video on Students' Listening Skill in Pandemic Situation. International Journal of Elementary Education, 5(3).

Goh, C. C. (2000). A Cognitive Perspective on Language Learners' Listening Comprehension Problems. System, 28(1), 55-75.

Goh, C. C., \& Hu, G. (2013). Exploring The Relationship Between Metacognitive Awareness and Listening Performance with Questionnaire Data. Language Awareness, 23(3), 255274.

Halim, A., Mukminatien, N., \& Anugerahwati, M. (2018). The Students' Perceptions Towards Authentic Materials for Reading and Listening Activities. Getsempena English Education Journal, 5(2), 150-161.

Hartshorn, K. J., \& McMurry, B. L. (2020). The effects of the COVID-19 pandemic on ESL learners and TESOL practitioners in the United States. International Journal of TESOL Studies, 2(2), 140-156.

Huang, M. (2021). A Case Study of ESL Students' Remote Speaking Class Learning Experiences in a Canada University During the COVID-19 Pandemic. Journal of English Language Teaching and Applied Linguistics, 3(5), 32-44.

Lall, S., \& Singh, N. (2020). CoVid-19: Unmasking The New Face of Education. Int. J. Res. Pharm. Sci., 48-53.

Lee, Y. J. (2018). Investigating the Relationship Between Metacognitive Awareness and Listening Comprehension in University Students. 응용언어학, 34(4), 201-225.

Nation, I. S. P., \& Newton, J. (2009). Teaching ESL/EFL Listening and Speaking. New York, NY: Routledge.

Nurkhamidah, N. (2021). University Students' Perspective on Material and Activities in English Listening Class During Pandemic. Elsya: Journal of English Language Studies, 3(2), 94-105.

Rahimi, M., \& Abedi, S. (2014). The Relationship between Listening Self-efficacy and Metacognitive Awareness of Listening Strategies. Procedia-Social and Behavioral Sciences, 98, 1454-1460.

Rahimi, M., \& Katal, M. (2011). Iranian University Students' Metacognitive Listening Strategies Awareness in Learning English. In third national conference on education, Tehran, Iran.

Rost, M. (2002). Teaching and Researching Listening. London, UK: Longman.

Selamat, S., \& Sidhu, G. K. (2011). Student Perceptions of Metacognitive Strategy Use in Lecture Listening Comprehension. Language Education in Asia, 2(2), 185-198.

Schmidt, A. (2016). Listening Journals for Extensive and Intensive Listening Practice. English Teaching Forum, 2(54) 2-11.

Song, L., \& McNary, S. W. (2011). Understanding Students' Online Interaction: Analysis of Discussion Board Postings. Journal of Interactive Online Learning, 10(1). 
Volume 6 Issue 23 (November 2021) PP. 81-94 DOI: 10.35631/JISTM.623007

Special Issue: Foundation Program Education Post-Covid-19: Issues and Opportunities

TafarojiYeganeh, M. (2013). Metacognitive Listening Strategies Awareness in Monolingual Versus Bilingual EFL Learners. Procedia-Social and Behavioral Sciences, 70, 17871793.

Takei, A. (2002). What Should Be Identified About Listening? In A. Takei (Ed.), Consideration of Listening In English: Inquiring Scientifically Listening Comprehension And Instruction. Tokyo: Kagensha

Vandergrift, L. (2004). Listening to Learn or Learning to Listen? Annual Review of Applied Linguistics, 24, 3-25.

Vandergrift, L. (2006). Second Language Listening: Listening Ability or Language Proficiency? The Modern Language Journal, 90(1), 6-18.

Vandergrift, L. \& Goh, C. (2012). Teaching and Learning Second Language Listening: Metacognition in Action. New York: Routledge.

Vandergrift, L., Goh, C., Mareschal, C., \& Tafaghodtari, M. H. (2006). The Metacognitive Awareness Listening Questionnaire (MALQ): Development and Validation. Language Learning, 56, 431-462.

Wen, K. Y. K., \& Kim Hua, T. (2020). ESL Teachers' Intention in Adopting Online Educational Technologies during COVID-19 Pandemic. Journal of Education and E-Learning Research, 7(4), 387-394. 